\title{
Molecular characterization using SSR markers in 50 shrub pea genotypes (Pisum sativum L.) from the GRICAND Collection, Colombia
}

\section{Caracterización molecular con marcadores SSR para 50 genotipos de arveja arbustiva (Pisum sativum L.) de la Colección GRICAND, Colombia}
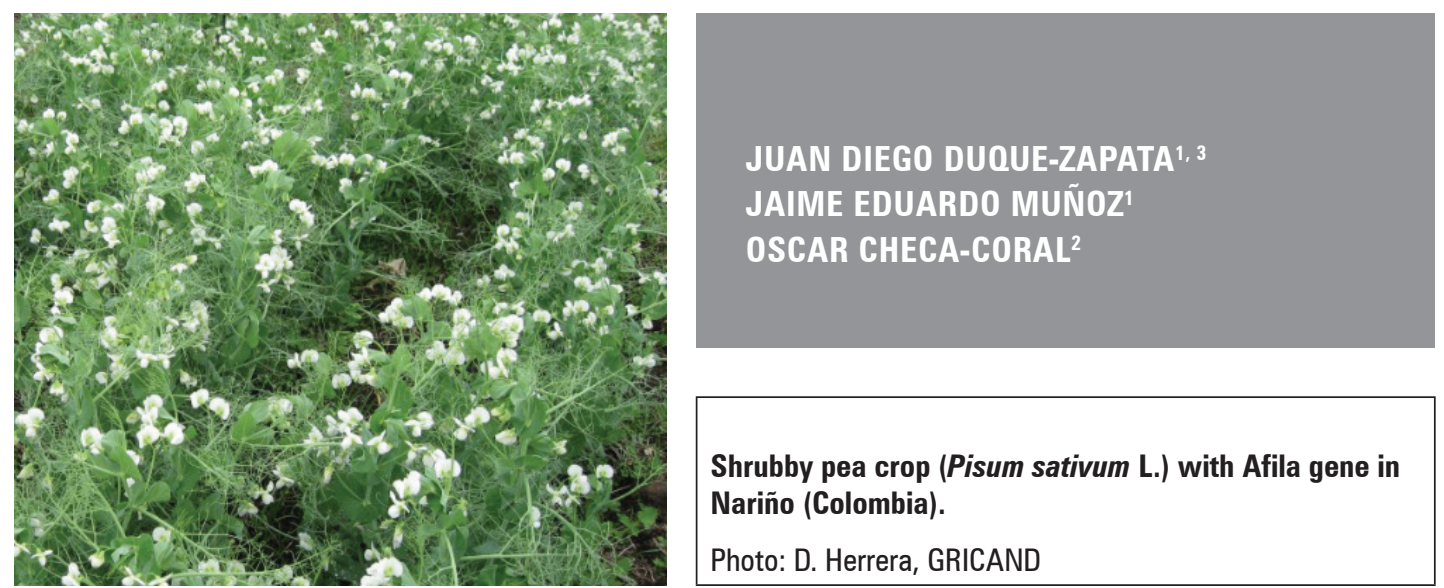

Shrubby pea crop (Pisum sativum L.) with Afila gene in Nariño (Colombia).

Photo: D. Herrera, GRICAND

\begin{abstract}
The pea (Pisum sativum L.) is one of the more important legume crops produced globally. We studied the structure and genetic diversity in a collection of 50 pea accessions with 16 simple sequence repeat (SSR) markers, whose average polymorphic information content (PIC) was 0.62 . The SSR markers amplified a total of 28 alleles with an average of 4 alleles per locus, with locus AB71 and D21 amplifying the largest number of alleles (6). The observed heterozygosity (Ho) was $0.09 \pm 0.08$ and the expected heterozygosity (He) was 0.42 , indicating an elevated level of inbreeding $\left(\mathrm{F}_{\mathrm{is}}=0.60\right)$. The genetic relationships were inferred with a similarity index (DICE) and a bayesian analysis (STRUCTURE), detecting 2 clusters for the genotypes, with a high similarity of the morphological characteristics of each genotype. The results of this study will be useful for the creation of future breeding programs.
\end{abstract}

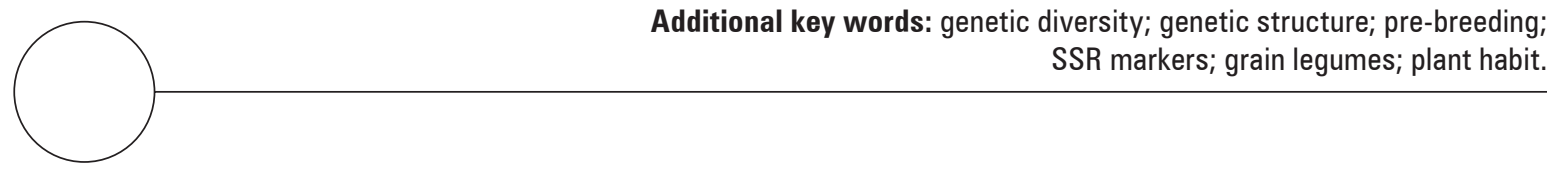

\footnotetext{
Universidad Nacional de Colombia, Facultad de Ciencias Agropecuarias, Palmira (Colombia). ORCID Duque-Zapata, J.D.: 0000-0001-5496-2502; ORCID Muñoz, J.E.: 0000-0002-8237-0499

2 Universidad de Nariño, Facultad de Ciencias Agrícolas, San Juan de Pasto (Colombia). ORCID Checa-Coral, O.: 00000002-6929-7717

3 Corresponding author.jduquez@unal.edu.co
} 


\section{RESUMEN}

La arveja (Pisum sativum L.) es uno de los cultivos de leguminosas más importantes producido a nivel mundial. Estudiamos la estructura y diversidad genética en una colección de 50 accesiones de arveja con 16 marcadores de Secuencias simples repetidas (SSR), cuyo promedio del contenido de información polimórfica (PIC) fue de 0,62. Los marcadores SSR amplificaron un total de 28 alelos con un promedio de 4 alelos por locus, siendo el locus AB71 y D21 los que amplificaron el mayor número de alelos (6). La heterocigosidad observada (Ho) fue de 0,09 y la esperada $(\mathrm{He})$ de 0,42 , indicando un alto nivel de endogamia $\left(\mathrm{F}_{\mathrm{is}}=0,60\right)$. Se infirieron las relaciones genéticas por medio de un análisis de similitud (DICE) y un análisis bayesiano (STRUCTURE) detectando 2 agrupaciones para los genotipos de arveja analizados, con una alta similitud con las características agromorfológicas de cada genotipo. Los resultados del presente estudio serán útiles para la creación de futuros programas de fitomejoramiento en arveja.

Palabras clave adicionales: diversidad genética; estructura genética; marcadores SSR; pre-mejoramiento; leguminosas de grano; hábito de crecimiento.

Received for publication: 23-05-2019 Accepted for publication: 31-07-2019

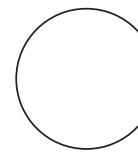

INTRODUCTION

Pisum sativum, known as pea or sweet pea, is a selfpollinated legume, with a genome made up of seven chromosomes $(2 n=14)$ (Smýkal et al., 2008). It is one of the staple foods of the basic market basket of the Colombian family because of its high content of protein and micronutrients, such as zinc and iron (Amarakoon et al., 2012; Peralta et al., 2013).

It is possible to find shrub-type peas, semi shrub-type peas and snowy-peas within $P$. sativum. Shrub peas are low-bearing, and their growth ends in flower, semi-shrubs are medium-sized peas that end in leaflets and snowy peas are high, require a tutor and end in leaflets. Two types of planting are used: with tutor and crawling planting without tutor or broadcast planting. Planting with a tutor generates high yields and a higher fresh pod quality; however, one of the limiting factors in this production system is the cost of the tutoring because the structure of the plants does not have enough tendrils to be left on the tutors without the plants falling on the ground; a high usage of polypropylene threads is necessary for their mooring (Checa-Coral and Rodriguez, 2015).

In Colombia, the pea is the second most important legume, after the bean, with a cultivated area of 35,211 ha and a green pod yield of $4.1 \mathrm{t} \mathrm{ha}^{-1}$. Its production is concentrated in six departments: Nariño, Cundinamarca, Boyaca, Tolima, Huila, and Nariño, the latter being the main producer with 15,816 ha (Checa-Coral and Rodriguez, 2015). This department has suitable areas for producing shrub peas, a suitable alternative for diversification in the cereal zone of Nariño because of its capacity for adaptation, high yield potential and possibility of harvesting green pods or dry-grained sheaths, depending on market conditions. However, in Nariño, the varieties of peas include snowy peas, which require tutoring systems to help the plant stay off the ground, allowing an increase in potential yield. According to Checa-Coral et al. (2017), employing a tutoring system represents $52 \%$ of total crop costs, which has led farmers with limited finances to not use tutored systems for the cultivation of peas, significantly increasing the incidence of foliar diseases such as mildew (Erysiphe polygoni) and Ascochyta (Ascochyta pisi), reducing yield and deteriorating quality of the final product. Because of technification difficulties in snowy pea tutoring systems, studies on shrub peas are vital, within which genotypes with the Afila gene $(\mathrm{a} F)$ are found, which, in the homozygote condition, transforms leaves into tendrils (Mike, 2008; Smýkal et al., 2013), reducing tipping and preventing the sheaths from coming into contact with the ground, avoiding pod rotting under high relative humidity conditions (Checa-Coral et al., 2017). This type of pea with a shrub growth habit tends to obtain low-bearing and early genotypes, with sheath qualities for fresh 
consumption and for the agro=industry (Checa-Coral et al., 2017). This material is adapted to the cereal zone and, with an adequate harvest time, could be an alternative to partially cover the national demand for dry peas and for producers to obtain good profitability because of the low cost of implementation of this crop.

Given the importance of shrub peas as a crop in the Department of Nariño-Colombia, it is necessary to initiate genetic improvement programs for genotypes with this growth habit. It is advisable to carry out molecular characterization of collections that allow breeders to identify genes of interest to associate them with agronomic characteristics and thus generate results that express genetic diversity. Knowledge on genetic diversity fosters the efficient use of germplasm, identifying and eliminating duplicates, and helps the establishment of nucleus collections (Ghafoor et al., 2005). Genetic diversity is the main input for the genetic improvement of a cultivated species. Local and wild varieties are kept in germplasm banks as genetic resources; however, their use in genetic performance improvement has been limited (Ali et al., 2007).

One of the most used molecular methods for characterization and genetic diversity studies are molecular markers. Microsatellites have become the most used markers because of their high polymorphism and easy handling in the laboratory; these markers have the ability to differentiate homozygous and heterozygote individuals. These markers consist of DNA fragments with a few nucleotides in length, between 2 and 6 base pairs, which are randomly repeated several times (Vieira et al., 2016). In 2005, a research group established sets of specific SSR microsatellites for P. sativum (Loridon et al., 2005), which have been used in several studies to observe the genetic diversity of the pea; for example, 21 SSR markers were used in a collection of more than 1,000 introductions. Zong et al. (2009) found that the genetic diversity of the Chinese collection has several differences that were detected in the global gene pool, such as the presence of rare alleles. These markers have been used in various studies over the years thanks to their high polymorphic information content, codominance and reproducibility (Smýkal et al., 2008; Cieslarová et al., 2011; Rana et al., 2017).
SSRs have also been used for studies of disease resistance; for instance, it has been found that resistance to Aphanomyces euteiches (cause of rotten root) is moderately heritable (Hamon et al., 2011).

Having specific pea genotypes of determined growth or shrubs adapted to the region, for which an adequate cultivation technology is established, improves the income of farming families in municipalities that used to be wheat producers in Nariño and allows farmers to return to agricultural activities by generating new work opportunities (ChecaCoral et al., 2017).

The aim of this work was to carry out the molecular characterization of 50 shrub pea genotypes from the collection of the GRICAND Research Group of the Universidad de Nariño, using SSR microsatellite molecular markers to serve as a starting point for the establishment of breeding programs for the species.

\section{MATERIALS AND METHODS}

\section{Plant material}

The study population was formed by 50 genotypes of $P$. sativum with a shrub-like growth habit, which are part of the Pisum sativum L. collection of the GRICAN Research Group on Andean Crops of the Universidad de Nariño. Sowing and germination of the plant material was carried out during the last three weeks of September, 2018 in the greenhouse of the Universidad Nacional de Colombia, Palmira Campus. Three plants of each genetic material were sown, and the sowing was carried out in germinators used for seedlings. When the plants were approximately $10 \mathrm{~cm}$ high, young leaflets were extracted, collecting approximately $5 \mathrm{~g}$ of foliar tissue which was stored in ultra-freezers at $80^{\circ} \mathrm{C}$. Simultaneously and in order to renew the seed in the Servicio Nacional de Aprendizaje of Colombia - SENA, 50 pea genotypes were multiplied in the field, using furrows $2 \mathrm{~m}$ in length with a distance between furrows of $60 \mathrm{~cm}$, depositing one seed per site. The lot was used to register the characteristics of leaf type and grain form based on UPOV descriptors (UPOV, 2009) (Tab. 1). 
Table 1. Morphological characteristics of leaf type and grain form for 50 genotypes of Pisum sativum $\mathrm{L}$.

\begin{tabular}{|c|c|c|}
\hline Genotype & Leaf type & Grain form \\
\hline ARB001 & 3 & 2 \\
\hline ARB002 & 3 & 2 \\
\hline ARB003 & 3 & 2 \\
\hline ARB004 & 3 & 4 \\
\hline ARB005 & 3 & 2 \\
\hline ARB006 & 3 & 4 \\
\hline ARB007 & 3 & 4 \\
\hline ARB008 & 3 & 4 \\
\hline ARB009 & 3 & 4 \\
\hline ARB010 & 3 & 4 \\
\hline ARB011 & 3 & 4 \\
\hline ARB012 & 3 & 4 \\
\hline ARB013 & 3 & 3 \\
\hline ARB014 & 3 & 4 \\
\hline ARB015 & 3 & 4 \\
\hline ARB016 & 3 & 3 \\
\hline ARB017 & 3 & 4 \\
\hline ARB018 & 3 & 4 \\
\hline ARB019 & 3 & 4 \\
\hline ARB020 & 3 & 4 \\
\hline ARB021 & 3 & 4 \\
\hline ARB022 & 3 & 4 \\
\hline ARB023 & 3 & 4 \\
\hline ARB024 & 3 & 4 \\
\hline ARB025 & 1 & 1 \\
\hline
\end{tabular}

\begin{tabular}{|c|c|c|}
\hline Genotype & Leaf type & Grain form \\
\hline ARB026 & 1 & 1 \\
\hline ARB027 & 1 & 1 \\
\hline ARB028 & 1 & 1 \\
\hline ARB029 & 1 & 4 \\
\hline ARB030 & 1 & 1 \\
\hline ARB031 & 1 & 1 \\
\hline ARB032 & 1 & 4 \\
\hline ARB033 & 1 & 4 \\
\hline ARB034 & 1 & 4 \\
\hline ARB035 & 1 & 4 \\
\hline ARB036 & 1 & 4 \\
\hline ARB037 & 1 & 4 \\
\hline ARB038 & 1 & 4 \\
\hline ARB039 & 1 & 2 \\
\hline ARB040 & 1 & 4 \\
\hline ARB041 & 1 & 4 \\
\hline ARB042 & 1 & 2 \\
\hline ARB043 & 1 & 4 \\
\hline ARB044 & 1 & 2 \\
\hline ARB045 & 1 & 4 \\
\hline ARB046 & 1 & 1 \\
\hline ARB047 & 1 & 1 \\
\hline ARB048 & 1 & 4 \\
\hline ARB049 & 1 & 1 \\
\hline ARB050 & 1 & 1 \\
\hline
\end{tabular}

Leaf type: $1=$ normal or terminated in tendril, $3=$ without leaves, tendril only. Grain form: $1=$ round, $2=$ angular round, $3=$ elongated oval, $4=$ several rectangular shapes.

\section{DNA extraction}

The SPIN Plant Mini Kit ${ }^{\circledR}$ (STRATEC Biomedical AG, Birkenfeld, Germany) with its respective procedure was used for the DNA extraction. The quantification of the genetic material was carried out with a Colibri Spectrophotometer ${ }^{\circledR}$ (Titertek-Berthold, Pforzheim, Germany) to obtain more precise measurements. The DNA dilutions were carried out for the normalization and homogenization of DNA concentration, with values of $30 \mathrm{ng} \mu \mathrm{L}^{-1}$, for the subsequent molecular evaluations with PCR reactions.

\section{Genotyping}

The genotyping used 16 molecular microsatellite fluorescent markers (SSR), described by Loridon et al. (2005) (Tab. 2). These markers were subjected to a process of standardization to determine what was the best hybridization temperature of each one. Subsequently, the amplification of the samples was done with the PCR technique.

Once products of amplification were obtained, the markers were mixed in plates with 96 wells where 
PCR products were combined; each well contained a maximum of three markers, which could not be the same color (PET, VIC, FAM, NED) and had to have distant molecular weights. These plates were sent to the laboratories of Macrogen (Seoul) for the analysis of the fragments of the SSR microsatellites.

\section{SSR microsatellites statistical analysis}

The size of the alleles in base pairs, was estimated using standard lane size ROX-500 (Applied Biosystems, Foster City, CA) with GENEIOUS Software ${ }^{\circledR}$ $\mathrm{v} 11.1$ (http://www.geneious.com) (Kearse et al., 2012). The number of polymorphic alleles observed, expected heterozygosity, and genetic diversity of Nei (1973), were observed using Arlequin Program v 3.5.2.2 (Excoffier and Lischer, 2010). Likewise, the Polymorphic Information Content was calculated (Botstein et al., 1980).

For a distance or similarity analysis, two methodologies may be used: a Principal Coordinates Analysis (PCoA) or a dendrogram (tree diagrams). A PCoA generates a scattering graph that can have two or three dimensions, where the distances between the samples shown in the graph reflect the genetic distances between them. On the other hand, a dendrogram performs a grouping of the samples that are genetically similar (Nisar et al., 2017). The PCoA was carried out using GenAlex v 6.5 program (Peakall and Smouse, 2012). On the other hand, the dendrogram was performed considering the created matrix and the similarity method of UPGMA/DICE using the Simqual programs of the NTSYS-PC package (Rohlf, 2006).

To assess the genetic structure of the genotypes, Structure v 2.3.4 was used (Falush et al., 2007). The criteria recommended by Porras-Hurtado et al. (2013) were used: the number of subpopulations (K-value) was 1-10, with 10 runs, for a Burn-in period of 100,000 steps and 200,000 interactions of the Monte Carlo Markov Chain (MCMC). To determine the best K, the method of Evanno et al. (2005) was considered. The Structure Selector Program was used (http://Imme.qdio.ac.cn/StructureSelector/). These steps were repeated the necessary times until the structural behavior of the samples was clearly defined. In order to determine a significant genetic differentiation between the possible groups created in Structure, an analysis of molecular variance was carried out (AMOVA), along with determination of using Arlequin v 3.5.2.2 (Excoffier and Lischer, 2010).

Table 2. SSR markers employed in research with their sequence forward and backward, hybridization temperature and molecular weight.

\begin{tabular}{|c|c|c|c|c|}
\hline Marker & Forward sequence 5'-3' & Reverse sequence $5^{\prime}-3$ ' & $\mathrm{Tm}^{\mathrm{a}}$ & Molecular size \\
\hline AA5 & TGCCAATCCTGAGGTATTAACACC & CATTTTTGCAGTTGCAATTTCGT & 61 & 235 \\
\hline AA355 & AGAAAAATTCTAGCATGATACTG & GGAAATATAACCTCAATAACACA & 51 & 180 \\
\hline AB53 & CGTCGTTGTTGCCGGTAG & AAACACGTCATCTCGACCTGC & 51 & 120 \\
\hline AD147 & AGCCCAAGTTTCTTCTGAATCC & AAATTCGCAGAGCGTTTGTTAC & 61 & 330 \\
\hline D21 & ТАТТСТССТССААААТТТССТТ & GTCAAAATTAGCCAAАTTCCTC & 51 & 200 \\
\hline AA122 & GGGTCTGCATAAGTAGAAGCCA & AAGGTGTTTCCCCTAGACATCA & 61 & 190 \\
\hline AA135 & CCGTTACACATCATTAAGATG & TCCATATCCAGATTAGTCAGA & 51 & 291 \\
\hline AD146 & TGCTCAAGTCAATATATGAAGA & CAAGCAAATAGTTGTTTTGTTA & 51 & 390 \\
\hline AD148 & GAAACATCATTGTGTCTTCTTG & TTCСATCACTTGATTGATAAAC & 54 & 190 \\
\hline AA238 & TATCATCAAGGTCCAATTTAGT & AGCTAAATCGTACCTAATCTGT & 51 & 190 \\
\hline D23 & ATGGTTGTCCCAGGATAGATAA & GAAAACATTGGAGAGTGGAGTA & 51 & 170 \\
\hline AB71 & CСАACСАTTTGTGAGTTCCСTT & TTCGTCGAACCACGAGAATAGA & 61 & 145 \\
\hline AD60 & CTGAAGCACTTTTGACAACTAC & ATCATATAGCGACGAATACACC & 51 & 216 \\
\hline AC58 & TCCGCAATTTGGTAACACTG & CGTCCATTTCTTTTATGCTGAG & 61 & 205 \\
\hline AD175 & CTTGTGCAGAAGCATTTGATTA & AGAGACAATGGATGCTCATAGT & 55 & 405 \\
\hline
\end{tabular}

$\mathrm{Tm}^{\mathrm{a}}$ : hybridization temperature. 


\section{RESULTS AND DISCUSSION}

\section{Analysis of SSR microsatellites}

Seven out of the 16 markers showed polymorphisms, and 27 alleles were found within the 50 genotypes (Tab. 3). Loci with a greater allelic richness included AB71 and AD21, with 6 alleles each. The average number of alleles was 4, with a range of 2 to 6 alleles per locus (Tab. 3); this result is greater than that reported by Ahmad et al. (2012) but similar in other studies on the Pisum genus (Cupic et al., 2009; Ponnaiah et al., 2011) and less than that reported by Hagenblad et al. (2014), where a range of 5 to 12 alleles was found, as was recently reported by Rana et al. (2017). The size of the alleles had a range of 50493 base pairs. The polymorphic information content (PIC) had an average of 0.62; according to Botstein et al. (1980), this value indicated that the markers were highly informative since they were above 0.50 and indicated that there could be an allelic variation within the samples. Similar values were reported in other pea research (Nasiri et al., 2009; Ahmad et al., 2012). Studies that have evaluated a larger number of Pisum accessions have observed a larger allele, indicating that some markers may become more polymorphic depending on the number of accessions that have been implemented (Ahmad et al., 2012). The inbreeding coefficient $\left(\mathrm{F}_{\mathrm{is}}\right)$ was 0.60 which indicated that there was a level of inbreeding, which explained that the observed heterozygosity (Ho) was less than the expected heterozygosity $(\mathrm{He})(0.09$ and 0.42 , respectively). This indicated that there was a high homozygosity normal behavior in the P. sativum individuals because of its pollinated nature (self-fertilization).
The low observed heterozygosity has been reported in other research on P. sativum: Handerson et al. (2014) obtained a Ho of 0.031, Smýkal et al. (2008) obtained a Ho of 0.069 with a collection from the Czech Republic and Teshome et al. (2015) used a collection of P. sativum from Ethiopia, finding a Ho of 0.05 , which confirms that $P$. sativum is a species that tends towards homozygosis (Teshome et al., 2015). On the other hand, according to Vallejo and Estrada (2002), in autogamous plants (such as Pisum sativum), inbreeding is expected to give a value equal or very close to one (1). Likewise, loci AB71 and AA135 had Ho values of 0.20 and 0.16 , respectively. The inbreeding values and Ho values could be explained by the fact that the seeds were obtained through open field sowing, which increased the probability that pollinating insects visited the flowers. Some research has suggested that the main pollinators of Pisum belong to the order of diptera, hymenopteros and lepidoptera (Naeem et al., 2018). In addition, in some cases, Pisum pistil may remain in a suitable state after anthesis (Kosterin and Bogdanova, 2014). These factors could suggest that the inbreeding and Ho resulted from the existence of some cases of allogamy or crosspollination in the collection.

\section{Genetic diversity}

In the dendrogram (Fig. 1A), two main groups were observed with a similarity coefficient (DICE) of approximately 0.74 (Group I and Group II). With an approximate coefficient of similarity of 0.93 , most of the sub-groups (15 subgroupings) were formed, which were highly related to the groups formed with the PcoA (Fig. 1B). In Group 1 of the dendrogram, sub-groups of genotypes with a high coefficient

Table 3. SSR markers with annealing temperature (Ta), number of alleles (Na), effective number of alleles (ENA), allele size range, polymorphic information content (PIC), observed heterozygosity (Ho) and expected heterozygosity (He), inbreeding coefficient $\left(\mathrm{F}_{\mathrm{is}}\right)$.

\begin{tabular}{|l|c|c|c|c|c|c|c|c|}
\hline \multicolumn{1}{|c|}{ Marker } & TA $\left({ }^{\circ} \mathrm{C}\right)$ & Na & ENA & $\begin{array}{c}\text { Allele size } \\
\text { BP range }\end{array}$ & PIC & Ho & He & $F_{\text {is }}$ \\
\hline AA122 & 62 & 5.0 & 2.12 & $155-195$ & 0.70 & 0.05 & 0.53 & 0.91 \\
\hline AA5 & 59 & 4.0 & 3.07 & $229-241$ & 0.69 & 0.07 & 0.67 & 0.89 \\
\hline D21 & 51 & 6.0 & 3.46 & $185-278$ & 0.74 & 0.16 & 0.71 & 0.77 \\
\hline AB71 & 59 & 6.0 & 4.65 & $304-334$ & 0.81 & 0.20 & 0.79 & 0.75 \\
\hline AA135 & 54 & 2.0 & 1.17 & $114-119$ & 0.40 & 0.16 & 0.15 & -0.09 \\
\hline AD60 & 52 & 2.0 & 1.08 & $50-58$ & 0.50 & 0.00 & 0.08 & 1.00 \\
\hline AA355 & 56 & 2.0 & 1.02 & $483-493$ & 0.50 & 0.02 & 0.02 & -0.01 \\
\hline Average & & 4.0 & 2.00 & - & 0.62 & 0.09 & 0.42 & 0.60 \\
\hline
\end{tabular}


A

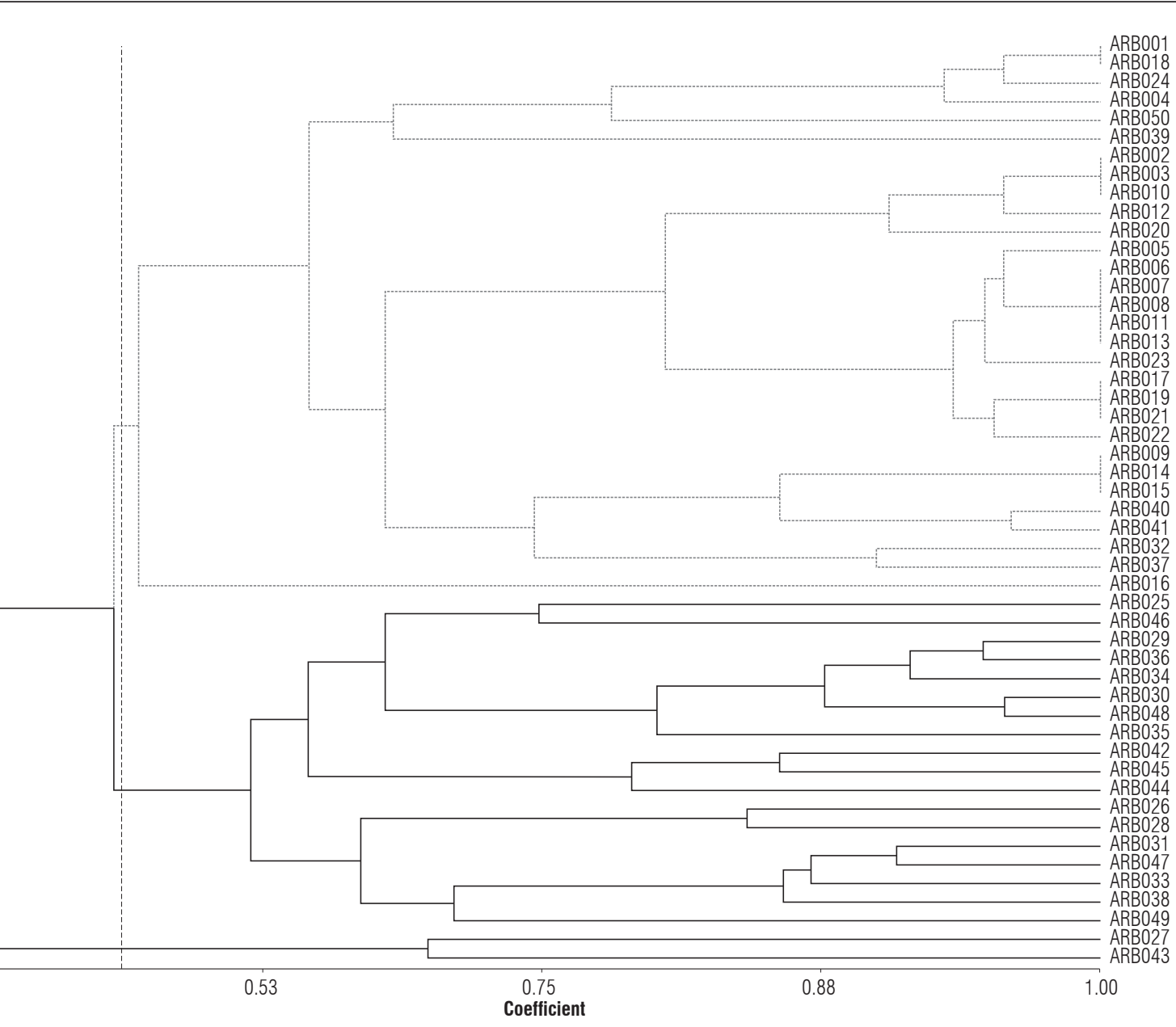

B

Principal Coordinates ( $\mathrm{PCOA})$

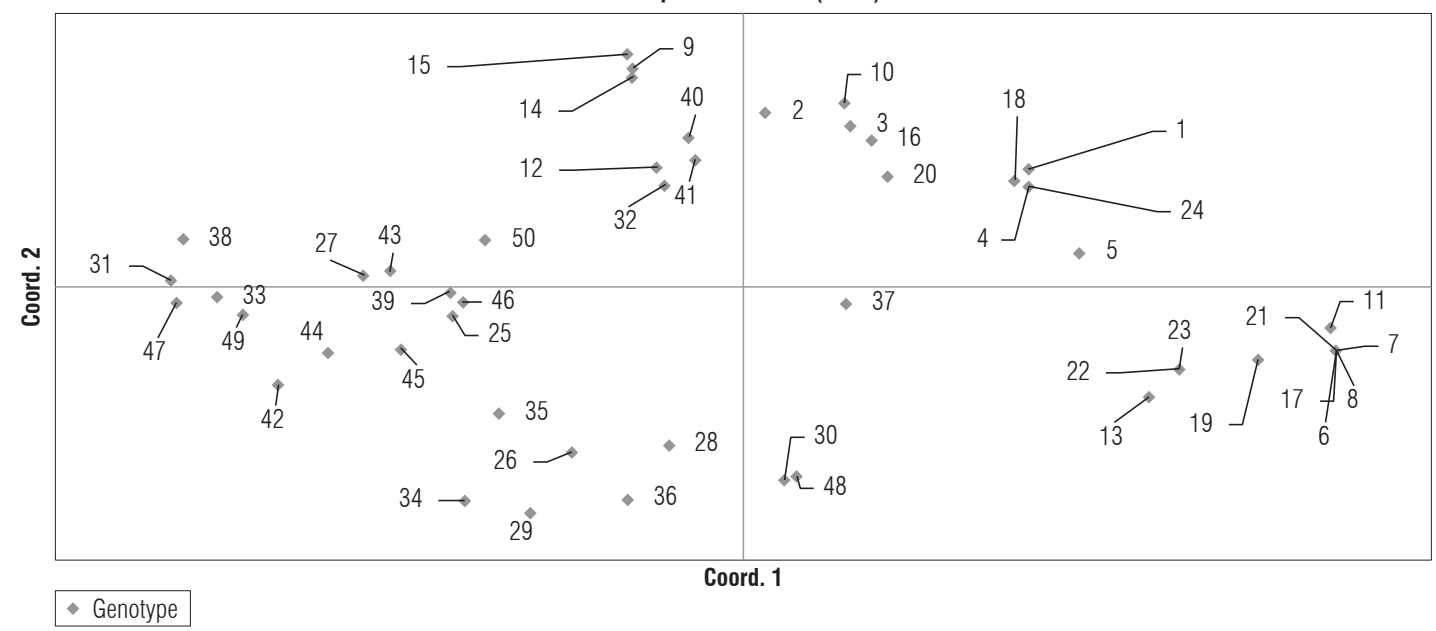

Figure 1. Similarity analysis for 50 genotypes of $P$ sativum with SSR markers: A) Dendrogram using the DICE/UPGMA method. B) Analysis of main coordinates (PCoA). 
of similarity $(<0.98)$ are observed, such as ARB 004 with 024; ARB 006 with 007, 008, 017 and 021; and ARB 022 with 023, among others. These high similarities could have been the product of the genotypes used in this study, with a very small population, a shrub growth and a particular area: Department of Nariño, along with sharing the same morphological characteristics.

The graph of main coordinates analysis (Fig. 1B) was carried out with the first two coordinates, which explained $51.20 \%$ of the total variation within the samples. Coordinate one explained $29.32 \%$, and coordinate two explained $21.88 \%$. By observing the groupings formed in the dendrogram (Fig. 1A) and in the PCoA analysis (Fig. 1B), it was observed that they were highly associated.
The analysis of the structure of the 50 P. sativum accessions showed a $\mathrm{K}=2$ with the higher hierarchical level of the genetic structure, which was supported by the Bayesian analysis (Fig. 2A). These two groupings (Group I and Group II) formed by the STRUCTURE analysis were highly associated with the groups found in the dendrogram. The accessions separated in two groups by STRUCTURE, in the same way as groups I and II of the dendrogram. On the other hand, the AMOVA analysis showed a FST value of $21.92 \%(P<0.00001)$, indicating that there was significant genetic differentiation between the two large groupings. Because the structure analysis was performed for each of the two groups separately, each group threw a hierarchy level $\mathrm{K}=2$, which indicated that each group has two subgroups (Fig. $2 \mathrm{~B}$ and $2 \mathrm{C})$.

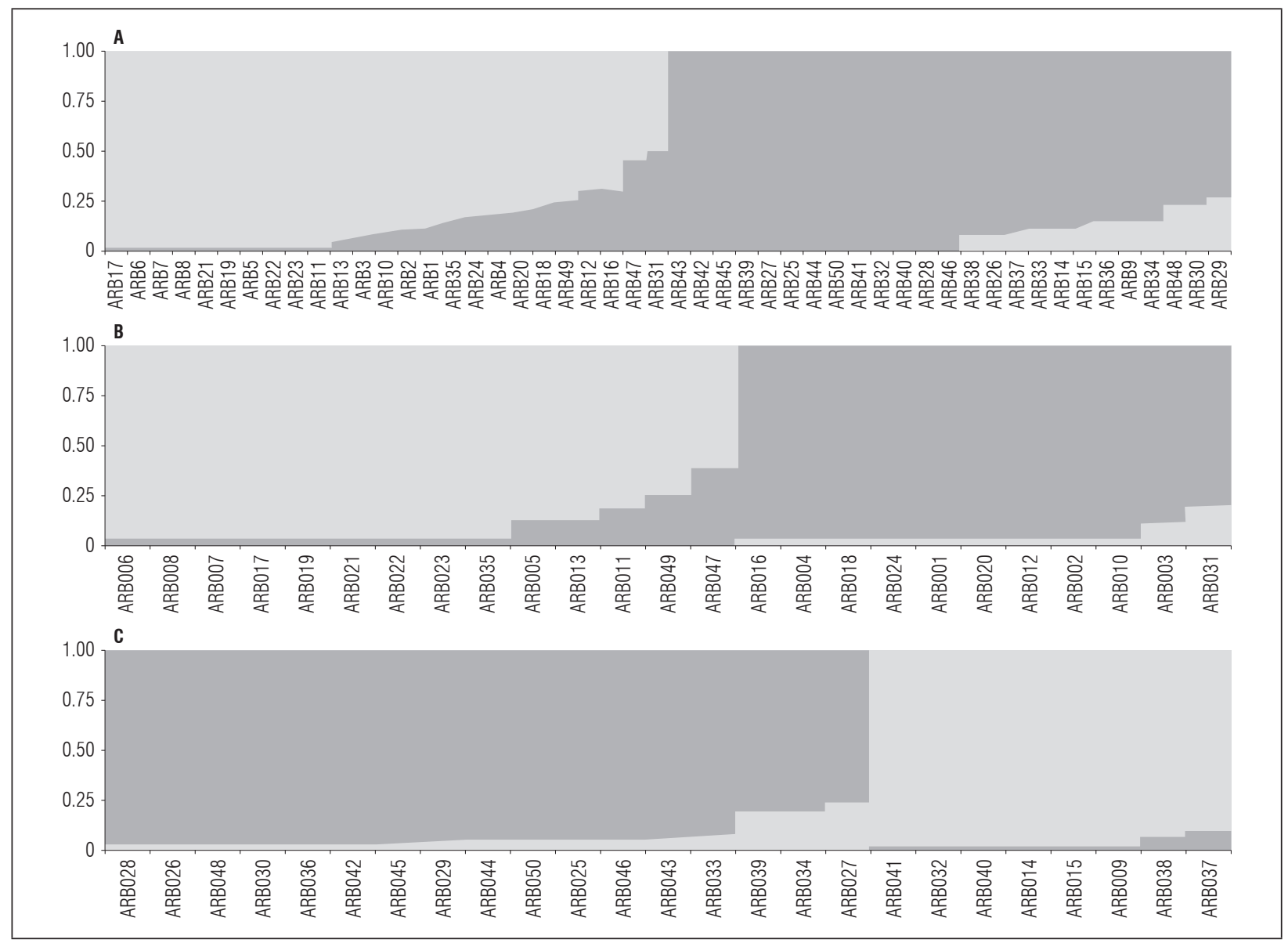

Figure 2. A) Bayesian analysis of the genetic structure $(K=2)$ in the 50 shrub pea genotypes based on seven microsatellite loci. B) Bayesian analysis of the genetic structure $(K=2)$ in group I (Group I) of the shrub pea genotypes. C) Bayesian analysis of the genetic structure $(\mathrm{K}=2$ ) in group II (Group II) of the shrub pea genotypes. Each bar equals an individual genotype. 
These $\mathrm{K}$ values have been demonstrated by Nasiri et al. (2009) and Ahmad et al. (2012), where a $\mathrm{K}=$ 2 were obtained. Other authors have reported some not very distant groups with $\mathrm{K}=3$ (Jing et al., 2012; Rana et al., 2017). The high similarity between the groups found in both the dendrogram, PCoA and STRUCTURE may have been due to the fact that the genotypes in the same group may share similar morphological features. According to the morphological traits (Tab. 1), it was observed that most genotypes belonging to group I had a sharp blade form (without leaves), with tendrils only and a rectangular grain form in several forms. It was observed that the genotypes of grouping II had a normal leaf form with lateral leaflets that finished in tendrils and, like Group I, a rectangular grain form in various forms. Morphological level differences were not found for the subgroups.

Finally, this is the first study that employed SSR microsatellite markers for the study of genetic diversity in the Pisum sativum Collection of the Department of Nariño (Colombia). Understanding the collection of P. sativum with the Afila gene is of great importance for the horticultural sector since it prevents the deterioration of product quality by reducing foliar diseases.

Although the use of SSR can be an effective tool for characterizing germplasm, for future research, it is recommended to have information at the geographic level on the origin of the genotypes, which will allow a much more complete system for the analysis of diversity and the possible development of new growths.

\section{CONCLUSION}

This study demonstrated the usefulness of molecular markers for molecularly characterizing $P$. sativum pea accessions. Understanding the richness of alleles is a priority and a significant help in different breeding and replanting programs since they are a pillar for better development of this crop. The morphological traits used in this study, along with the molecular points, explained the differences found within and between the accessions. The results of the diversity and genetic structure are useful for identifying contrasting groups to guide the selection of parents. The genetic variability between the accessions was sufficiently high, suggesting that the genetic diversity of the pea is sufficient for the possible combination of favorable genes.

Using these results as a first step, a self-pollination process of several generations shall follow in order to obtain pure lines. Hence, it is necessary to integrate genetic, morphological, disease resistance and production results to establish a possible relationship with the data obtained and, thus, be able to propose improvement programs. Research is currently underway to adjust planting distances, densities and economic analyses to exploit the productive potential of these genotypes.

In the future, the release of the first volatile variety with the Afila gene for the country is expected. These new varieties reduce the costs of tutoring (52\%) by half or more.

Conflict of interests: The manuscript was prepared and reviewed with the participation of the authors, who declare that there exists no conflict of interest that puts at risk the validity of the presented results.

\section{BIBLIOGRAPHIC REFERENCES}

Ahmad, S., M. Singh, N.D. Lamb-Palmer, M. Lefsrud, and J. Singh. 2012. Assessment of genetic diversity in 35 Pisum sativum accessions using microsatellite markers. Can. J. Plant Sci. 92(6), 1075-1081. Doi: 10.4141/ cjps2011-261

Ali, Z., A.S. Qureshi, W. Ali, H. Gulzar, M. Nisar, and A. Ghafoor. 2007. Evaluation of genetic diversity present in pea (Pisum sativum L.) germplasm based on morphological traits, resistance to powdery mildew and molecular characteristics. Pak. J. Bot. 39(7), 2739-2747.

Amarakoon, D., D. Thavarajah, K. McPhee, and P. Thavarajah. 2012. Iron-, zinc-, and magnesium-rich field peas (Pisum sativum L.) with naturally low phytic acid: a potential food-based solution to global micronutrient malnutrition. J. Food Comp. Anal. 27(1), 8-13. Doi: 10.1016/j.jfca.2012.05.007

Botstein, D., R.L. White, M. Skolnick, and R.W. Davis. 1980. Construction of a genetic linkage map in man using restriction fragment length polymorphisms. Am. J. Hum. Genet. 32(3), 314-331.

Checa-Coral, O.E., J.E. Bastidas-Acosta, and O.C. NarváezTaimal. 2017. Evaluación agronómica y económica de arveja arbustiva (Pisum sativum L.) en diferentes épocas de siembra y sistemas de tutorado. Rev. U.D.C.A Act. \& Div. Cient. 20(2), 279-288. Doi: 10.31910/rudca. v20.n2.2017.380 
Checa-Coral, O. and M. Rodriguez. 2015. Resistencia a oídio (Erysiphe polygoni) y rendimiento en arveja afila (Pisum sativum L.). Temas Agrarios 20(2), 58-71. Doi: 10.21897/rta.v20i2.759

Cieslarová, J., P. Hanáček, E. Fialová, M. Hýbl, and P. Smýkal. 2011. Estimation of pea (Pisum sativum L.) microsatellite mutation rate based on pedigree and single-seed descent analyses. J. Appl. Genet. 52(391), 391-401. Doi: 10.1007/s13353-011-0058-9

Cupic, T., M. Tucak, S. Popovic, S. Bolaric, S. Grljusic, and V. Kozumplik. 2009. Genetic diversity of pea (Pisum sativum L.) genotypes assessed by pedigree, morphological and molecular data. J. Food Agric. Environ. 7(34), 343-348.

Evanno, G., S. Regnaut, and J. Goudet. 2005. Detecting the number of clusters of individuals using the software STRUCTURE: a simulation study. Mol. Ecol. 14(8), 2611-2620. Doi: 10.1111/j.1365-294X.2005.02553.x

Excoffier, L. and H.E.L. Lischer. 2010. Arlequin suite ver 3.5: a new series of programs to perform population genetics analyses under Linux and Windows. Mol. Ecol. Resourc. 10(3), 564-567. Doi: 10.1111/j.1755-0998.2010.02847.x

Falush, D., M. Stephens, and J.K. Pritchard. 2000. Inference of population structure using multilocus genotype data: dominant markers and null alleles. Mol. Ecol. Notes 7(4), 574-578. Doi: 10.1111/j.1471-8286.2007.01758.x

Ghafoor, A., Z. Ahmad, and R. Anwar. 2005. Genetic diversity in Pisum sativum and a strategy for indigenous biodiversity conservation. Pak. J. Bot. 37(1), 71-77.

Hamon, C., A. Baranger, C.J. Coyne, R.J. McGee, I. Le Goff, V. L'Anthoëne, R. Esnault, J.-P. Rivière, A. Klein, P. Mangin, K.E. McPhee, M. Roux-Duparque, L. Porter, H. Miteul, A. Lesné, G. Morin, C. Onfroy, A. Moussart, B. Tivoli, R. Delourme, and M.-L. Pilet-Nayel. 2011. New consistent QTL in pea associated with partial resistance to Aphanomyces euteiches in multiple French and American environments. Theor. Appl. Genet. 123 261-281. Doi: 10.1007/s00122-011-1582-z

Handerson, C., S.K. Noren, T. Wricha, N.T. Meetei, V.K. Khanna, A. Pattanayak, S. Datt, P.R. Choudhury, and M. Kumar. 2014. Assessment of genetic diversity in pea (Pisum sativum L.) using morphological and molecular markers. Indian J. Genet. Plant Breed. 74(2), 205212. Doi: 10.5958/0975-6906.2014.00157.6

Jing, R., M.A. Ambrose, M.R. Knox, P. Smykal, M. Hybl, Á. Ramos, C. Caminero, J. Burstin, G. Duc, L.J.M. van Soest, W.K. Święcicki, M.G. Pereira, M. Vishnyakova, G.F. Davenport, A.J. Flavell, and T.H.N. Ellis. 2012. Genetic diversity in European Pisum germplasm collections. Theor. Appl. Genet. 125(2), 367-380. Doi: 10.1007/s00122-012-1839-1

Kearse, M., R. Moir, A. Wilson, S. Stones-Havas, M. Cheung, S. Sturrock, S. Buxton, A. Cooper, S. Markowitz,
C. Duran, T. Thierer, B. Ashton, P. Meintjes, and A. Drummond. 2012. Geneious basic: an integrated and extendable desktop software platform for the organization and analysis of sequence data. Bioinformatics 78(12), 1647-1649. Doi: 10.1093/bioinformatics/ bts199

Kosterin, O.E. and V.S. Bogdanova. 2014. Efficiency of hand pollination in different pea (Pisum) species and subspecies. Indian J. Genet. Plant Breed. 74(1), 50-55. Doi: 10.5958/j.0975-6906.74.1.007

Loridon, K., K. McPhee, J. Morin, P. Dubreuil, M.L. Pilet-Nayel, G. Aubert, C. Rameau, A. Baranger, C. Coyne, I. Lejeune-Hènaut, and J. Burstin. 2005. Microsatellite marker polymorphism and mapping in pea (Pisum sativum L.). Theor. Appl. Genet. 111(6), 1022-1031. Doi: 10.1007/s00122-005-0014-3

Mike, A. 2008. Garden pea. pp. 3-26. In: Prohens, J. and F. Nuez (eds.). Handbook of plant breeding. Vol. 2: Vegetables II: Fabaceae, Liliaceae, Solanaceae, and Umelliferae. Springer, New York, NY. Doi: 10.1007/978-0-387-74110-9_1

Naeem, S., S. Ahmad, M. Hassan, M. Adil, M.A. Younis, M. Azeem, and M. Ibrahim. 2018. Role of pollinators in pea (Pisum sativum) yield at Peshawar valley. J. Entomol. Zool. Stud. 6(2), 1280-1282.

Nasiri, J., A. Haghnazari, and J. Saba. 2009. Genetic diversity among varieties and wild species accessions of pea (Pisum sativum L.) based on SSR markers. Afr. J. Biotech. 8(15), 3405-3417.

Nei, M. 1973. Analysis of gene diversity in subdivided populations. Proc. Natl. Acad. Sci. USA 70(12), 33213323. Doi: 10.1073/pnas.70.12.3321

Nisar, M., A. Khan, S.F. Wadood, A.A. Shah, and F. Hanci. 2017. Molecular characterization of edible pea through EST-SSR markers. Turk. J. Bot. 41(4), 338-346. Doi: 10.3906/bot-1608-17

Peakall, R. and P.E. Smouse. 2012. GenAlEx 6.5: genetic analysis in Excel. Population genetic software for teaching and research - an update. Bioinformatics 28(19), 2537-2539. Doi: 10.1093/bioinformatics/ bts460

Peralta, E., A. Murillo, N. Marzón, J. Pinzon, and E. Villacrés. 2013. Manual agrícola de frijol y otras leguminosas: cultivos, variedades y costos de producción. Publicación Miscelánea 135. $3^{\text {th }}$ ed. INIAP, Quito.

Ponnaiah, M., E. Shiferaw, M.E. Pè, and E. Porceddu. 2011. Development and application of EST-SSRs for diversity analysis in Ethiopian grass pea. Plant Genet. Resour. 9(2), 276-280. Doi: 10.1017/S1479262111000426

Porras-Hurtado, L., Y. Ruiz, C. Santos, C. Phillips, Á. Carracedo, and M.V. Lareu. 2013. An overview of STRUCTURE: applications, parameter settings, and supporting software. Front. Genet. 4, 98. Doi: 10.3389/fgene.2013.00098 
Rana, J.C., M. Rana, V. Sharma, A. Nag, R.K. Chahota, and T.R. Sharma. 2017. Genetic diversity and structure of pea (Pisum sativum L.) germplasm based on morphological and SSR markers. Plant Mol. Biol. Rep. 35(1), 118-129. Doi: 10.1007/s11105-016-1006-y

Rohlf, F.J. 1987. NTSYS-pc: microcomputer programs for numerical taxonomy and multivariate analysis. Am. Stat. 41(4), 330. Doi: 10.2307/2684761

Smýkal, P., C. Coyne, R. Redden, and N. Maxted. 2013. Peas. pp. 41-80. In: Singh, M., H.D. Upadhyaya, and I.S. Bisht (eds.). Genetic and genomic resources of grain legume improvement. Elsevier Science, London.

Smýkal, P., M. Hýbl, J. Corander, J. Jarkovský, A.J. Flavell, and M. Griga. 2008. Genetic diversity and population structure of pea (Pisum sativum L.) varieties derived from combined retrotransposon, microsatellite and morphological marker analysis. Theor. Appl. Genet. 117(3), 413-424. Doi: 10.1007/s00122-008-0785-4

Teshome, A., T. Bryngelsson, K. Dagne, and M. Geleta. 2015. Assessment of genetic diversity in Ethiopian field pea (Pisum sativum L.) accessions with newly developed EST-SSR markers. BMC Genet. 16(1), 102. Doi: 10.1186/s12863-015-0261-5

UPOV. 2009. Guidelines for the conduct of tests for distinctness, uniformity, and stability of Pisum sativum L. TG/7/10 Rev. International Union for the Protection of New Varieties of Plants, Geneva.

Vallejo, F.A. and E.I. Estrada. 2002. Mejoramiento genético en plantas. Universidad Nacional de Colombia, Palmira, Colombia.

Vieira, M.L.C., L. Santini, A.L. Diniz, and C.F. Munhoz. 2016. Microsatellite markers: what they mean and why they are so useful. Genet. Mol. Biol. 39(3), 312328. Doi: 10.1590/1678-4685-GMB-2016-0027

Zong, X., R.J. Redden, Q. Liu, S. Wang, J. Guan, J. Liu, Y. Xu, X. Liu, J. Gu, L. Yan, P. Ades, and R. Ford. 2009. Analysis of a diverse global Pisum sp. collection and comparison to a chinese local $P$. sativum collection with microsatellite markers. Theor. Appl. Genet. 118, 193-204. Doi: 10.1007/s00122-008-0887-z 